\title{
DIALÉTICA E EVOLUÇÃO
}

Carlos R. V. Cime-Lima

SINTTESE - Dialéticos e analíticos não se entendem porque falam línguas com sintaxes parcialmente diferentes. Não obstante esta diferença, há três principios básicos que regem e estruturam tanto a lógica dialética como a lógica analítica: os príncípios de identidade, de diferença e de coerência universal. Os mesmos três príncípios regem também a natureza em seu processo de evolução e constituem o indivíduo e a espécie (pr. de identidade), as mutaçōes por acaso (pr. da diferença) e a seleção natural (pr. de coerência).
ABSTRACT - Dialeticians and analytical philosophers don't understand each other, because use in their languages different syntaxes. In spite of this a difference, there are three basic principles ruling and structuring the dialectical as well as the analytical logic, namely the prineiple of identity, of difference and of universal coherence, The same three principles rule also the nature in its process of evolution and constitute the individual and the species (principle of identity), the mutations by chance (principle of difference) and natural selection (principle of coherence).

Analíticos e dialéticos argumentam e disputam, uns com os outros, sem jamais se entender. É porque eles falam línguas diversas, cada uma com suas características próprias. São duas línguas diferentes com sintaxes diferentes. Os analíticos, para dizer e expressar algo, utilizam frases ou proposiçōes compostas de sujeito, predicado e cópula (respectivamente de argumento e função); somente tais construções sintáticas possuem um valor de verdade, apenas elas, não os conceitos, são verdadeiros ou falsos. Na linguagem dialética, porém, tais proposições compostas de sujeito e predicado não são, via de regra, utilizadas na argumentação. As "idéias" de Platão e os "conceitos" de Hegel possuem sempre um valor de verdade e sempre apresentam algo como verdadeiro ou falso (as idéias se atraem mutuamente, elas entram em conflito e se repelem, elas se conciliam e se reunificam), mas quase nunca se desdobram explicitamente em sujeito e predicado. Esta diferença fundamental de estrutura sintática dá a ambas as línguas características próprias, tornando-as radicalmente diferentes uma da outra. Aí reside a razão mais profunda por que analíticos e dialéticos discutem uns com os outros sem jamais se entender. Se quisermos nos entender, há que se fazer a tentativa de captar o que é dito numa língua, pegar o pensamento puro (como se isso fosse possível), e depois reformulá-lo e traduzi-lo para a outra língua. Ora, tanto nas ciências como também nas falas articuladas de nosso dia-a-dia utilizamos hoje quase exclusivamente a linguagem analítica com sua estrutura própria constante de sujeito e predicado ex-

- Pontificia Universidade Católica do Rio Grande do Sul, PUCRS 
plícitos; hoje este modo de falar analítico é considerado, se não sempre claro e absolutamente evidente, pelo menos facilmente compreensivel por todos. É por isso que, partindo do mais claro para o mais obscuro, fazemos aqui a tentativa de dizer em linguagem analítica o que é dialética.

Na primeira parte tratamos da dialética na Lógica, isto é, no âmbito do pensar e do falar. Na segunda parte mostramos como este modelo, desenvolvido a partir da Lógica e para ela válido, se aplica também à natureza; afirmamos que os mesmos princípios, que regem o pensar e o falar e determinam o processo lógico do discurso, são também válidos para a natureza e regem, nela, a evolução de todas as coisas. Os primeiros princípios do pensar são também princípios do ser; a Lógica transforma-se, assim, numa Filosofia da Natureza. Numa terceira parte mostramos que o mesmo modelo se aplica também à Filosofia do Espírito, isto é, à Ética, à Teoria do Estado e à Filosofia da História. Com isso, a partir da dialética, ficam esboçadas, sob a forma de um projeto, as três partes de um Sistema de Filosofia.

\section{1-LÓGICA}

1 - Os princípios: Três princípios determinam e ordenam tanto o pensamento analítico como o pensamento dialético: o Princípio da Identidade, o Princípio da Diferença e o Princípio da Contradição a ser evitada. Conforme estes princípios se interdeterminam e se inter-relacionam, surgem processos mentais diversos; um deles chamamos pensamento analítico, outro, pensamento dialético.

1.1 - O Princípio da Identidade, que diz e afirma como verdadeiro que " $\mathrm{A}$ " é "A", é pressuposto, quase sempre tacitamente, na linguagem analiticamente articulada, que utilizamos de maneira predominante no linguajar de nosso dia-a-dia acadêmico. Há aí, implícitos, três momentos ou subprincípios do Princípio de Identidade que precisamos aqui - depois veremos por quê - explicitar e desdobrar.

1.1.1 - A identidade simples não pode ser ulteriormente explicada, ela é simples. Quando se diz ou escreve algo, como, por exemplo, "A", então há aí uma identidade simples. Este "A" destaca-se de seu pano de fundo e do meio ambiente que o circunda, ele é algo determinado e diz algo determinado. Mas este dizer é apenas um primeiro começo no qual não se pode parar. Quem diz "A" está dizendo algo, sim, mas diz muito pouco e ficamos esperando pelo que deve ser acrescentado a seguir. Em vez de "A", poder-se-ia colocar aí qualquer outro sinal, por exemplo, um quadrado ou um círculo.

1.1.2 - A identidade iterativa ocorre quando ao primeiro "A" se acrescenta um segundo " $A$ ": " $A$ " e "A". Ou ainda um terceiro, um quarto, etc.: "A", "A", "A", " $A$ " etc. Enquanto a iteração continua, ou seja, enquanto o " $A$ " se repete, não surge nada de novo. Esta identidade iterativa é, entretanto, de grande importância, pois é através dela que a fala e o discurso entram em movimento.

1.1.3 - A identidade reflexa emerge quando ao primeiro " $\mathrm{A}$ " se contrapõe, em identidade, um outro "A": "A" = "A". Aqui a identidade é, pela primeira vez, ex- 
pressa plenamente. É a partir daqui que se pode falar normalmente, isto é, de maneira analiticamente normal, pois somente a partir daqui temos - distintos um do outro - sujeito e predicado lógicos. Ao invés de " $\mathrm{A}=\mathrm{A}$ ", poderíamos escrever também, como acima sugerido, " $\mathrm{O}=\mathrm{O}$ ". $\mathrm{O}$ principio da identidade é aquilo que constitui a tautologia. As lógicas da identidade descrevem as múltiplas formas e variaçōes de tautologia que ocorrem em línguas determinadas, cada qual com sua sintaxe própria.

1.2 - O Princípio da Diferença: A diferença, isto é, a verdadeira e plena alteridade, surge quando se acrescenta ao "A" algo que não é apenas um mero " $\mathrm{A}$ ". Diferença, dita de forma bem geral, é sempre o Não-A. Ou, para usar outro exemplo, quando ao quadrado se acrescenta algo que não é quadrado, como um círculo ou um triângulo, então surge a diferença. $\mathrm{O}$ que é diferente está sempre em oposição ao que é idêntico a si mesmo; esta diferença pode ser contraditória ou contrária. Em ambos os casos há uma negação, só que num caso ela é mais forte que no outro.

1.2.1 - A diferença entre contraditórios: Se ao "A" é acrescentado um "Não-A", temos aí dois conceitos que são contraditórios. Tudo o que existe e tudo o que, como meramente possível, pode existir está contido ou em " $\mathrm{A}$ " ou em "Não$\mathrm{A}$ ". A soma de "A" e de "Não-A" contém tudo, ela abrange tanto o universo das coisas existentes como também todos os mundos possiveis. Conceitos contraditórios são construidos sempre que se nega de forma estrita o conceito inicial, positivo, de que se parte.

1.2.2 - A diferença entre contrários: Quando, porém, opomos a "A", não o conceito abrangente de "Não- $\mathrm{A}$ ", que contém tudo que não é " $\mathrm{A}$ ", mas simplesmente algo diferente de " $\mathrm{A}$ ", então temos um contrário. $\mathrm{O}$ conceito assim formado, que está em oposição contrária a " $\mathrm{A}$ ", não é uma negação universal, mas sim uma negação determinada, como, por exemplo, "B", ou "C", ou " $\mathrm{D}$ " etc. A soma de conceitos contrários não é o universo das coisas, mas tão somente um conjunto limitado; neste caso sempre datur tertium. "B" está em oposição contrária a "A", mas isso não impede que existam - ou possam existir -, além disso, ainda " $C$ ", " $D$ " etc. $O$ conceito contrário não pode ser deduzido da identidade, isto é, ele não pode ser construído pela simples negação de um conceito inicial positivo. Um tal contrário é, sob o ponto de vista lógico-formal, algo originário, isto é, algo imediato e primordial que não pode ser derivado de um conceito anterior. Um tal contrário não pode ser deduzido nem explicado a partir da identidade, nem através de iteração, nem através de reflexăo da própria identidade. $\mathrm{O}$ diferente de repente está ai, presente, na fala ou no pensamento, sem que ele possa ser explicado ex ante. Antes da emergência do diferente há, em princípio - por Lógica -, só o idêntico, sua iteração e sua reflexão sobre si mesmo, não há, porém, a diferença. É neste sentido que o diferente, que de repente surge e se opõe ao idêntico, é algo que ocorre, é algo que acontece, isto é, é algo contingente. Ele acontece, ele ocorre, ele é fruto do acaso. Contingência e acaso constituem aqui - naquilo que é diferente por oposição contrária - uma ruptura com a identidade e significam tanto um enriqueci- 
mento como também um perigo para o discurso. Quando ao " $\mathrm{A}$ " se acrescenta um "B", em tal caso é preciso que se examine se um combina e se ajusta com o outro. A possibilidade de combinação de um com o outro é determinada através do Princípio da Coerência, que também é chamado de Principio da Contradição a ser evitada.

\section{3 - O Princípio da Coerência ou Princípio da Contradição a ser evita-}

da: O Princípio da Contradição a ser evitada não diz que contradiçōes são impossíveis, diz apenas que contradiçōes não devem existir. No primeiro começo da Lógica não está, portanto, um "É impossível", mas um "Dever-ser", um operador modal deôntico que, mais tarde, irá se desdobrar como Ética. Este princípio normativo diz três coisas.

1.3.1 - O sentido universal: O Princípio da Contradiçăo a ser evitada diz que contradições não devem existir, embora elas às vezes de fato existam. Este é o sentido geral e universalmente válido do Princípio de Não-Contradição. Quem não aceita isso e nega o Princípio da Contradição a ser evitada nega a racionalidade do discurso. Quem diz algo e, ao mesmo tempo, se desdiz está fazendo bobagem. Nos discursos factuais que fazemos no dia-a-dia ou até na ciência ocorrem, às vezes, bobagens desse tipo; mas tais bobagens não deveriam ocorrer. Quem não vê isso, quem ignora a proibição expressa pelo Princípio de Não-Contradição - o que como fato pode ocorrer - vai se dar mal; o castigo vem em seguida. Uma tal pessoa, que diz algo e ao mesmo tempo se desdiz, não está a dizer nada. Tal pessoa abandona o discurso racional e só pode ficar muda como uma planta. Aristóteles tem aí toda a razão. Mas Aristóteles não tem razão quando, no livro Gama, usa o operador tradicional - o operador forte - e declara que é impossível predicar e não predicar o mesmo predicado do mesmo sujeito sob o mesmo aspecto e ao mesmo tempo. Isso - fora dos sistemas lógico-formais livres de contradição - não é impossível e sim indevido ou impróprio. Tal coisa não deveria ocorrer, isso não é racional, isso é bobagem. Este é também, em sua amplidão, o sentido e a definição de racionalidade. Racional é o discurso que se quer livre de contradições. Mas, se apesar disso ainda há contradições nos discursos que de fato empreendemos, o que fazer? Então o discurso racional não foi construído até o fim, ele não está pronto e acabado, em tal caso a racionalidade se encontra ainda no movimento processual de sua constituição. Em tais casos devem ser aplicados os subprincípios que estão contidos apenas implicitamente no Princípio de Não-Contradição, e que devem ser agora (em 1.3.2. e 1.3.3.) explicitados; esta explicitaçăo se faz aqui no sentido da grande tradição aristotélica. Estes subprincípios estão inicialmente justapostos. Para superar e vencer a contradição que de fato ocorreu é preciso aplicar um ou outro. De acordo com a tradição deve-se tentar aplicar, inicialmente, o primeiro subprincípio. Se este não resolver a questão, então há que se aplicar o segundo.

1.3.2 - A anulação de um dos dois pólos opostos: O primeiro subprincípio do Princípio de Não-Contradição ensina que dito e contradito às vezes se opōem de tal maneira que um deles é verdadeiro e o outro é falso. Em tais casos a racionalidade do discurso exige que se guarde a proposição verdadeira; a outra deve-se 
jogar fora por ser falsa. Este subprincipio do Princípio de Não-Contradição não possui validade universal; ele não é oniabrangente. A anulação de um dos dois pólos opostos ocorre muitas vezes, mas não sempre. É nesta anulação de um dos pólos opostos que se enraíza aquilo que chamamos de analítica. A anulação de um dos dois pólos opostos faz-se de acordo com as regras do "Quadrado Lógico", como a seguir se expõe.

1.3.2.1 - Dito e contradito podem estar, um para com o outro, em oposição contraditória. A regra para isso é a seguinte: Duas proposições contraditórias não podem ser simultaneamente verdadeiras, nem simultaneamente falsas. Se uma proposição é verdadeira, a proposição a ela oposta de forma contraditória é sempre e necessariamente falsa. E, ao inverso, se a primeira proposição é falsa, a segunda é sempre verdadeira. É, pois, impossivel que ambas sejam simultaneamente verdadeiras, ou que sejam simultaneamente falsas. Em todos estes casos um pólo da oposição sempre elimina o outro. $\mathrm{O}$ jogo dos opostos funciona aqui de modo que uma proposição anula completamente a outra; uma proposição é mantida como racional, a outra implode e é jogada fora do discurso.

1.3.2.2 - Dito e contradito podem também estar, um para com o outro, em oposição contrária. A primeira regra para isso é a seguinte: Se uma proposição é verdadeira, a proposição a ela oposta de maneira contrária sempre e necessariamente é falsa. Em tais casos um pólo anula o pólo contrariamente oposto, como vimos acima nas proposiçōes contraditórias. A segunda regra para isso diz: $\mathrm{Da}$ falsidade de uma proposição não se pode concluir a verdade da proposição a ela contrariamente oposta. Se, portanto, a primeira proposição é falsa, então não se fica sabendo se a outra é verdadeira ou falsa; ela pode ser verdadeira, mas pode ser, por igual, falsa. É por isso que a tradição diz: Proposições contrárias não podem ser simultaneamente verdadeiras, mas podem ser simultaneamente falsas. É impossivel que ambas as proposições sejam verdadeiras; isso, portanto, nunca ocorre. Mas é perfeitamente possivel que ambas as proposiçōes sejam falsas; isso pode ocorrer, isso às vezes ocorre. $\mathrm{O}$ que fazer se ambas as proposições são simultaneamente falsas? Os pólos da oposição, em tal caso, se anulam mutuamente? Deve-se. em tal caso, jogar fora ambas as proposições opostas? Não, não se deve fazer isso. Jogar fora ambas as proposições não leva ninguém adiante, e é preciso ir adiante. $\mathrm{O}$ segundo subprincipio do Princípio de Não-Contradição mostra como. Exatamente aqui é que a dialética se enraíza.

1.3.3 - A elaboração das devidas distinções: O segundo subprincípio do Princípio de Não-Contradição contém uma instrução muito importante que regula e determina o movimento processual do pensamento; ela pode ser formulada como segue. Se tanto o dito como também o contradito são ambos falsos (se não se pode manter uma das proposições como verdadeira, jogando a outra fora por ser falsa), então é preciso fazer, no sujeito, as devidas distinções. Desta maneira se evita que o mesmo predicado seja predicado e não predicado do mesmo sujeito sob o mesmo aspecto; isso não se deve fazer. Através desta distinção de aspectos diversos, indispensável para a elaboração e para a superação da contradição, o sujeito lógico 
da predicação é reduplicado. Na Idade Média chamava-se isso de propositio explicativa, em alguns casos de propositio reduplicativa. Em tal caso o mesmo atributo é predicado e não predicado do mesmo sujeito, mas sob aspectos diferentes. Este segundo subprincípio do Princípio de Não-Contradição, que - como o primeiro não possui validade universal e não está, desde sempre, efetivado, é o fundamento da dialética. Isso há que ser mostrado a seguir. Antes, porém, mencione-se e desdobre-se, passo por passo, um exemplo clássico da Lógica e da Ontologia tradicionais. Todas as mesas que aí existem são, por um lado, existentes e não podem, por isso, não existir; pelo outro lado, porém, todas estas mesas são contingentes e, por isso, tanto podem existir, como, por igual, não existir. Assim surgem dito e contradito, tese e antítese:

Tese: Estas mesas näo podem não existir

Antítese: Estas mesas podem não existir

Na tese é afirmada a impossibilidade do não-existir, na antítese, a possibilidade do não-existir. Na tese é afirmada a necessidade, na antítese, a contingência. Entre dito e contradito há uma oposição contrária e ambas as proposições, tomadas simplesmente como estão aí, são falsas. O que fazer? Fazer as devidas distinções, ensina a tradição. $\mathrm{E}$ assim são gerados dois aspectos diversos, o que restabelece o bom sentido:

Sujeito
Sujeito reduplicado 1
Predicado
Sujeito
Sujeito reduplicado 2
Predicado

- Estas mesas,

- enquanto elas de fato existem,

- não podem não existir

- Estas mesas,

- enquanto elas são contingentes,

- podem não existir

O sujeito lógico da predicação foi reduplicado através das duas propositiones explicativae que lhe foram acrescentadas. O sujeito originário foi mantido ("Estas mesas"), mas através das proposições explicativas ele foi reduplicado, e o sujeito lógico que era um só transformou-se em um sujeito duplo; sendo assim, de agora em diante não se predica mais do mesmo sujeito e sob o mesmo aspecto tanto necessidade como também a não-necessidade, isto é, a contingência. Através da reduplicação do sujeito lógico foram gerados dois novos aspectos que elaboram a contradição antes existente e a superam, de maneira que os pólos contrários são conciliados num nivel superior. A todas estas mesas que existem de maneira contingente cabe tanto necessidade como também contingência, só que sob aspectos diferentes. Através das distinções feitas a contradição que existia entre duas proposições contrárias foi trabalhada discursivamente e, assim, superada. Este modus procedendi é conhecido em toda a tradição e, como se sabe, é muito usado. Só que não nos damos conta, via de regra, que exatamente aqui, neste ponto, analítica $\mathrm{e}$ dialética se interligam. A analítica faz as devidas distinções e pensa, parcialmente com razão, que assim tudo ficou certo e correto; mas ela dá ênfase, aí, não à unidade do sujeito lógico originário, mas sim à duplicidade dos dois novos aspectos gerados, isto é, à dualidade que surgiu na reduplicação do sujeito. A dialética, ao 
contrário, põe a ênfase na unidade do sujeito lógico; ela acentua também a dualidade dos pólos contrários, mas não tematiza o engendramento dos dois novos aspectos que se acrescentam ao sujeito lógico originário. A analítica negligencia, assim, a unidade originária e considera o sujeito apenas como um sujeito duplo, isto é, como dois sujeitos lógicos; a dialética, ao inverso, não tematiza de que maneira os pólos contrários se conciliam na síntese de forma a nela coexistir sem implosão. Nos últimos cem anos a analítica, sob este aspecto, empobreceu mais ainda, pois ela pressupõe como sujeito lógico algo que está determinado até o último pormenor. A Lógica analítica, hoje, não se dá conta de que o sujeito lógico, na construção do discurso argumentativo, muitas vezes não está completamente determinado e que necessita, assim, de ulterior determinação através do engendramento de novos aspectos que se lhe acrescentam e que o tornam um conceito mais preciso. Este sujeito lógico, visto no movimento processual de seu engendramento, que na Idade Média era evidente, hoje é infelizmente desconhecido. Com isso perdeu-se também o elo que liga analítica e dialética.

2 - A estrutura da dialética: Na triade dialética tanto a tese quanto a antítese são, conforme a tradição, proposições falsas; só a sintese que delas resulta é que é verdadeira. Esta é a maneira de proceder no "jogo de contrários" de Platão, assim é em Hegel. Pressupomos, por isso, como hipótese de trabalho que tanto a proposição tética como a antitética sảo falsas, ou que ambas podem ser demonstradas como falsas. Duas proposições contraditórias, porém, jamais podem ser simultaneamente falsas; quando uma delas é falsa, a outra é, por necessidade lógico-formal, sempre verdadeira. Disso se conclui de maneira rigorosamente exata que tese e antítese não são proposiçōes contraditórias, mas, sim, proposições contrárias. Proposições contrárias não podem ser simultaneamente verdadeiras, mas podem ser simultaneamente falsas. Exatamente aqui - e somente aqui - abre-se o espaço no qual a dialética se desenvolve. A primeira conclusão importante a que chegamos é, portanto, que a dialética é, sim, o jogo dos contrários, jamais o jogo dos contraditórios. Expresso de outra maneira, significa que no discurso dialético tese e antitese só podem ser formuladas sob a forma de proposiçöes universais, uma delas positiva, a outra negativa. O sujeito lógico tanto da proposição tética como da antitética só pode ser um universal; trata-se, aí, falando a linguagem do "Quadrado Lógico" dos autores medievais, de proposições de tipo "A" (tese) e de tipo "E" (antitese).

\section{1 - Tese:}

2.1.1 - O sujeito lógico da predicação dialética: O que é este universal que é posto aí como sujeito lógico da predicação dialética? De que se fala quando se faz Lógica dialética? De que se fala quando se faz Filosofia Real? Platão e o Cusanus nos dão, a este respeito, indicações. Hegel nos diz clara e expressamente: na Lógica fala-se sempre do Absoluto. Na Lógica as assim chamadas categorias são atributos que são predicados de Deus. Assim como as categorias o dizem, assim é o Absoluto, assim é Deus antes de criar o mundo. De acordo com Hegel o sujeito lógico da predicação dialética é, pelo menos naquela parte do sistema que se cha- 
ma Lógica, sempre só o Absoluto. Mas como estamos esboçando um projeto de sistema que se quer critico, não podemos pressupor o Absoluto assim sem mais, como se fosse um tiro disparado de uma pistola; por isso, começamos com aquilo com o que o começo da ciência deve ser feito. Não pressupomos nada de determinado, nem mesmo o Absoluto enquanto determinado, fazemos assim um começo que não tem nenhuma pressuposição. Mas, quem não está a pressupor nada de determinado, pressupöe tudo de forma indeterminada. - Tomamos todas as coisas, sejam elas existentes ou apenas possiveis, e colocamo-las à esquerda de uma linha imaginária. À direita dessa linha há, de inicio, apenas um espaço vazio. Este è o espaço do sistema filosófico no qual deveremos repor criticamente tudo aquilo que foi pressuposto e, como tal, colocado à esquerda. Este "repor" é uma reconstruçāo, esta reconstrução é a Filosofia; o método da Filosofia é a dialética ; o sujeito lógico da proposição dialética é tudo aquilo que foi pressuposto de forma indeterminada: "Todas as coisas". A proposição dialética na Ciência da Lógica tem, portanto, sempre a seguinte forma: "Todas as coisas são $x "$ ", sendo que " $\mathrm{x}$ " aí significa um predicado. - Hegel, como se sabe, näo fala de "Todas as coisas" e sim do Absoluto, ou, na Fenomenologia, da verdade e essência de " $x$ " (A verdade e a essência da certeza sensível estão na subjetividade, respectivamente na objetividade, na conciliação de objetividade e subjetividade, etc.). Proponho a expressão "Todas as coisas" para que apareça com clareza maior que o sujeito lógico da predicação é um universal, que se trata aí de uma proposição com sujeito lógico universal; com isso diminui o perigo de que se confunda o contrário com o contraditório, o que levaria a aporias insolúveis.

\subsection{2 - O predicado lógico da primeira tese: Para formular uma primeira} proposição dialética, que se componha de sujeito e predicado logicamente explícitos e expressos, é preciso, além do sujeito lógico "Todas as coisas", de um predicado. Qual é este primeiro predicado? O que pode e deve ser dito de todas as coisas? O que é tão simples e tão universal que pode ser predicado de todas as coisas? Qual é esta primeira e simples determinação? Olhamos o espaço à esquerda da linha imaginária , onde tudo - isto é, todas as coisas - estão pressupostas de maneira indeterminada, e verificamos que tudo "é", que tudo está "sendo", que tudo de alguma maneira é ser. Aí levantamos a tese: "Todas as coisas são ser". Esta constatação, que aparece como a primeira tese do sistema, é uma determinação lógica ulterior, é uma diferenciação do sujeito lógico, ela diz algo a mais sobre o sujeito, algo que o sujeito já desde sempre era mas que não havia sido expresso. Essa diferenciação não se faz nem por dedução a priori nem por inferência lógica, ela é uma descrição hermenêutica. A gente olha para aquilo que foi pressuposto e constata que tudo "é". Isto é uma descrição hermenêutica. O método dialético lança mão neste exato lugar do método hermenêutico; isto significa que há um momento hermenêutico dentro daquele todo maior que é a dialética. Os predicados da proposição dialética não são, portanto, conceitos construídos a priori, e sim conceitos oriundos do espaço onde foram colocadas e onde se encontram todas as pressuposições. Os predicados da proposição dialética não são construídos, eles são encontrados: eles estão prejacentes e existem desde o começo à esquerda da linha imaginária onde está tudo aquilo que foi pressuposto. O filósofo sobrevoa com o olhar 
este espaço das coisas pressupostas e escolhe dentre elas (aí estão contidas também as determinações conceituais) aquele conceito que, por um lado, é oniabrangente e, pelo outro lado, tão simples que sirva de predicado para a primeira proposição do sistema. A procura e a descoberta de um tal conceito é um trabalho hermenêutico. E deste modo formula-se a primeira tese, que se revela como sendo falsa. Aqui começa a marcha da dialética.

2.1.3 - A demonstração da falsidade da tese: A tese que diz que todas as coisas são ser é uma proposição falsa. Este valor de verdade "é falso" não surge do nada; uma tal falsidade precisa ser demonstrada de maneira convincente. A marcha da dialética começa com uma tese que é falsa e passa por uma antítese que também é falsa, mas o método dialético como tal não sabe por si só se uma determinada proposição é verdadeira ou falsa. De ínício sabe-se tão somente - assim ensina a tradição filosófica - que apenas uma proposição falsa serve como tese ou antítese de uma triade dialética. Em se querendo falar de tese ou de antítese, é preciso sempre demonstrar que a referida proposição é falsa. Aqui, exatamente aqui é que o dialético utiliza o método analítico. - Com referência a esta primeira tese do sistema que diz que "Todas as coisas são ser", a falsidade da proposição emerge e fica patente quando se mostra a contradição performativa aí existente. Quem quer determinar alguma coisa e diz apenas que esta coisa a ser determinada é "ser", um tal falante determina algo como sendo indeterminado, ele determina algo como o ser indeterminado. Há nisso uma contradição performativa que torna evidente a falsidade da proposição. - A falsidade da tese (como também da antítese) precisa ser demostrada no curso da dialética, como aqui foi feito, de maneira analítica. Este é o lugar onde o método dialético se entrelaça com o método analíti$\mathrm{Co}$, ficando a Análise como momento interno dentro da Dialética. - Constatada a falsidade da tese, segue a marcha da dialética. A tese é falsa, não se pode, portanto, permanecer nela de maneira racional. O pensamento é expulso do âmbito da tese, e surge a antítese.

\section{2 - A antítese:}

2.2.1 - A gênese da antítese: A proposição antitética está, como foi mostrado mais acima, não em oposição contraditória e sim em oposição contrária à tese. Só assim é possivel que ambas, tese e antítese, sejam simultaneamente falsas; em oposiçōes contraditórias, uma sendo falsa, a outra é sempre verdadeira. Quando se trata de dialética, isto é, quando ambas, tese e antítese, são falsas, então sempre se trata de proposições que estão em oposição contrária. Isso significa que à tese "Todas as coisas são ser" deve ser contraposta a antitese "Todas as coisas não são ser" ou "Nada é ser". Isto está perfeitamente correto, pois proposições contrárias podem ser construídas a priori de maneira totalmente lógica. A gente parte de uma determinada proposição universal afirmativa e constrói a proposição universal negativa correspondente. Platão, o Cusano e Hegel, porém, procedem de outra maneira. Os dialéticos utilizam na elaboração de antíteses quase sempre um conceito novo que eles tiram do grande cesto onde se encontram todas as pressuposições que foram feitas no início. Os dialéticos não utilizam proposições bem formadas à 
maneira da analítica aristotélica, eles trabalham com "idéias" e com "conceitos" nos quais sujeito e predicado não estão desdobrados logicamente. Sem esta diferenciação, porém, entre sujeito lógico e predicado lógico, não se pode construir aprioristicamente proposiçōes contrárias. Quando os dialéticos, portanto, querem dizer um pólo contrário - não o contraditório -, eles têm que utilizar um conceito completamente diferente do que foi usado na tese. O conceito contrário a "amor" (philesis) não é "não-amor" e sim "contra-amor" (em grego antiphilesis); "não-amor" é o contraditório de "amor". Tomando-se "amor" e "não-amor" juntos, têm-se o universo de todas as coisas existentes e possíveis. Tomando-se, porém, "amor" e "contra-amor" juntos, têm-se apenas uma pequena parcela do universo, neste caso datur tertium. Opostos contraditórios, quando somados, totalizam o universo; contrários, não. Como os dialéticos não utilizam proposições bem formadas, constituídas de sujeito e de predicado, não lhes é possivel distinguir contrários e contraditórios apenas através de sua forma sintática; como, porém, lhes é indispensável fazer tal distinção, eles precisam lançar mão de conceitos completamente diferentes que expressem os pólos contrários. Os analíticos, entretanto, que distinguem oposições contrárias e contraditórias por sua forma sintática, não precisam fazer isso. Se quisermos dizer em linguagem analítica aquilo que os dialéticos estão a falar, então mister se faz aprender a tratar com ambas as formulações da antítese, com ambas as construçōes lingüísticas. A primeira é analítica e pode ser construída a priori, ela é a negação contrária da tese e diz "Todas as coisas não são ser", a segunda, a que é usada pelos dialéticos, diz "Todas as coisas são nada". Tais proposições que se repetem no curso ulterior do sistema nem sempre significam exatamente a mesma coisa. Este é o motivo por que é preciso muito cuidado na passagem de uma formulação para a outra, na elaboração e na interpretação de antíteses. Este é o lugar onde entra, de novo, a Hermenêutica.

2.2.2 - A falsidade da antítese: A falsidade da antítese tem que ser demonstrada por argumentos, em cada caso, sempre de novo. Esta demonstração é feita pelo método analítico. A primeira antítese do projeto de sistema "Todas as coisas săo nada" contém uma contradição performativa e é, por isso, racionalmente insustentável; este valor de verdade "é falso", sem o qual não há nenhuma antítese dialética genuína, foi obtido aqui através do método analítico. - Foi demonstrado que tanto a tese como a antítese são falsas. Isso não pode ficar assim, pois o espírito que permanece na falsidade perde sua racionalidade e vira contra-senso. Um tal espirito, deturpado como irracionalidade e contra-senso, de acordo com o Princípio de Não-Contradição, não deve ser. E é por isso que somos expelidos da posição tética e da posição antitética e precisamos procurar um espaço onde se possa morar racionalmente. Assim se chega à sintese dialética, na qual os pólos antes opostos de forma excludente se conciliam, já agora, sem contradição: coincidentia oppositorum. 


\section{3 - Síntese:}

2.3.1 - A descoberta e, respectivamente, a formação de sínteses: Sínteses devem existir. Pois não se pode morar na falsidade e na autocontradição. Se o fizermos, entretanto, viramos planta, viramos contra-senso e ficamos um ser monstruoso, e aí a longo prazo só há uma perspectiva: o processo corrosivo de autocontradição e, ao final, a autodestruição. A razão deve ser e é por isso que devemos procurar uma sintese sempre que formos expelidos de posições téticas e antitéticas. Uma tal sintese às vezes é descoberta já pronta, às vezes ela tem que ser engendrada. Se encontramos já pré-jacente na linguagem ou na História uma síntese pronta e acabada, ótimo; a tarefa do Filósofo consiste, então, em reconstruir logicamente essa conciliação de pólos que estavam em oposição contrária, e em examiná-la em sua coerência interna, como também em sua coerência com o restante do projeto de sistema, respectivamente, com o processo global do universo. Quando, porém, não se encontra uma síntese pronta e acabada, já preexistente, deve-se criar uma sintese que corresponda aos pólos contrários. Em tais casos a proposição sintética precisa ser inventada de forma criativa. Sínteses preexistentes e sínteses engendradas por criação têm uma característica em comum: nelas a contradição entre os pólos contrários foi superada e guardada (Der Widerspruch wurde aufgehoben).

Aufheben (superar e guardar) significa aqui, como em Hegel, tanto superar, dissolver, desfazer, como também guardar, conservar, manter. A contradiçäo existente entre tese e antítese é dissolvida; é bom que seja assim, pois contradições em princípio não devem existir. A contradição só é boa se e enquanto ela é superada (como aufgehoben). A dissolução da contradição acontece aqui da mesma forma que já os mestres pensadores da Idade Média indicavam, a saber, através da distinção de aspectos. É falso que todas as coisas sejam ser; é falso também que todas as coisas não sejam nada. As coisas pressupostas e colocadas à esquerda da linha imaginária são tanto ser como, por igual, nada. Ambas as proposiçōes têm como sujeito lógico "Todas as coisas"; o predicado da primeira é o "ser", o da segunda é o "nada". Ambas são falsas se cada predicado é tomado sozinho e isolado do outro. Se queremos fazer justiça à realidade, precisamos usar ambos os predicados ao mesmo tempo. Mas como eles são contrários, um contra o outro, um excluindo o outro, é preciso, então, distinguir aspectos. Esta distinção de aspectos em oposição à doutrina e à praxe dos pensadores aristotélicos da Idade Média não pode ser efetivada no âmbito do sujeito lógico; pois na Ciência da Lógica não se pode abandonar o sujeito universalíssimo da predicação dialética. Logo, é preciso fazer a necessária distinção no âmbito dos predicados. "Ser" e "nada" mostraramse predicados não satisfatórios e por isso precisam ser descartados. 0 que pode ser posto no lugar das determinações conceituais descartadas como impróprias? Agora é preciso olhar para o mundo pressuposto e nele procurar hermeneuticamente um predicado no qual tanto "ser" como também "nada" estejam superados e guardados em proporção igual. Aí a gente encontra - e aqui a Hermenêutica volta à baila - na linguagem e na tradição filosófica o conceito de "devir". No devir o ser fica nada e o nada fica ser. Por isso é que "devir" pode ser usado como predicado da proposi- 
ção sintética "Todas as coisas são devir". Esta proposição sintética é, agora, verdadeira.

Assim como é possível que exista mais de uma antítese, assim também pode ser que haja mais de uma sintese. Para o conceito de "amor" (philesis), por exemplo, há tanto o conceito antitético de "contra-amor" (antiphilesis), como o de "desamor", e também o de "ódio". Dependendo do que se toma como antítese, a sintese é outra.

Mesmo quando se trata da mesma antítese, ocorre freqüentemente que mais de uma sintese seja possivel. A síntese, por exemplo, entre facções em luta pode consistir em tréguas mais ou menos curtas, em tratados de paz com as mais variadas nuanças e até em compreensão fraternal. Diversas sínteses existem aí pré-jacentes, respectivamente, diversas formas sintéticas podem ser engendradas. Como se deve, por princípio, evitar contradições, a escolha da síntese é uma ação ética. Deve-se, na vida prática, escolher aquela síntese na qual a contradição está melhor superada e guardada. Em exercícios teóricos é necessário, para não perder a visão do conjunto, repassar diversas alternativas. A listagem completa e exaustiva de todas as antiteses e de todas as sinteses correspondentes não é algo factível, pois, como foi visto acima, as antíteses não são dadas (ou construídas) a priori e de forma necessária e sim a posteriori e de forma contingente. É por isso que o sistema de Filosofia dialética não é um sistema dedutivo e sim um sistema aberto, tão somente um projeto de sistema. Filosofia continua sendo apenas amor à sabedoria, sem jamais transformar-se num sistema completo e acabado do saber.

2.3.2 - Como a síntese de novo vira tese: Esta sintese é uma proposição verdadeira, pois todas as coisas estäo realmente em devir, elas são um devir. Mas esta proposição que se apresenta primeiramente como sendo verdadeira possui uma verdade apenas relativa, ela não é toda a verdade, ela não é a totalidade que deve ser. A verdade é o todo (per definitionem) e o todo é sempre mais do que uma primeira e provisória síntese. A proposição "Todas as coisas são um devir" não expressa devidamente a riqueza do mundo pressuposto à esquerda da linha imaginária. As coisas pressupostas são muito mais ricas e complexas do que aquilo que é dito pelo conceito "devir". Até o ato de pensamento e de fala que expressa isso já é muito mais do que aquilo que está sendo expresso pelo predicado. $O$ ato de pensar e falar determina aí, nesta predicação, o sujeito lógico de uma maneira insuficientemente determinada; isso é uma contradiçäo performativa, a qual se repete em todas as sinteses, exceto a última, e é isso que impulsiona sempre de novo a marcha da dialética.

Esta última síntese tem que existir. Pois o movimento da dialética existe de fato - estamos nele - e movimento de fato existente pressupõe e é sempre movimento possível; o movimento que é possivel pressupöe sempre que o último fim dele também é possivel. Pois o movimento para o impossível é um movimento para o nada, e um movimento para o nada é o nada do movimento, um tal movimento nâo se movimentaria. Ele se movimenta. Logo, conclui-se que a última síntese do movimento tem que ser possivel; isto é, a dialética não pode ser uma dialética apenas negativa. A idéia absoluta que pode ser é também algo que deve ser. - Não se pense, entretanto, que este fim último do movimento dialético seja externo ao pro- 
cesso dialético, isto é, que seja um ser tão somente transcendente. Pelo contrário, como o fim último desde sempre está sendo antecipado no movimento, como o ideal de estar livre de contradições está sendo sempre antecipado na realidade do discurso, como a transcendência sempre é um momento imanente pressuposto em cada etapa do processo dialético, a última síntese desde sempre existe e está dada de maneira circular. O fim aí vira um novo começo. Isto já deveria ser evidente, pois sintese é, por princípio, sempre de novo uma nova tese. Este é mais um motivo por que o sistema da Filosofia só pode ser articulado como um projeto de sistema, um sistema sempre aberto. A Filosofia continua sendo apenas amor à sabedoria, fragmentária e incompleta.

\section{2-NATUREZA}

2.1 - Dialética, como articulada por Platâo, Nicolau de Cusa e Hegel, é sempre Filosofia idealista. Idealismo está aqui em oposição a nominalismo e a realismo. O nominalismo - na Filosofia contemporânea, embora raramente sejam chamados assim, são numerosos os defensores desta doutrina - afirma que as leis do falar e do pensar valem tão somente para o falar e o pensar; é bobagem dizer que as mesmas leis que vigem para o falar e o pensar sejam válidas também para o ser. Quem garante que a gramática da linguagem seja também a gramática do mundo? Existe, por sinal, uma gramática que seja comum aos múltiplos jogos de linguagem? 0 realismo, ao contrário, tem como certo que pensar e ser são, em princípio, distintos um do outro, e que nem todas as leis que valem para um são também válidas para o outro, mas que existem, a fim e cabo, algumas leis do falar e do pensar que são também válidas para o ser. Quais leis possuem uma tal validade dupla, isto é, esta validade ampliada, é exatamente isso que se deve explorar e mostrar. Realistas honestos concedem abertamente que não é fácil mostrar essa correspondência. Em oposição a isso, afirma o idealismo - com o realismo - que as mesmas leis que valem para o falar e o pensar são válidas também para o ser, e - contra o realismo que falar, pensar e ser não são tão diferentes um do outro. Pensar e ser não são mundos contrapostos ou justapostos, mas apenas graus diferentes de efetivação, isto é, de evolução do mesmo princípio universal que tudo perpassa. Este princípio, o "logos" ou a "idéia", não é apenas um princípio do pensar, mas também, além disso e primeiramente, um princípio do ser. Como se demonstra uma tal afirmação? Devemos proceder da mesma maneira que os realistas, que no fundo são idealistas encabulados, mostrando que a gramática básica do falar e do pensar também é a gramática do mundo existente. É preciso mostrar que os mesmos princípios que vigem para o falar e o pensar sảo também válidos para o mundo. Dizendo a mesma coisa de outra forma: é preciso mostrar que os mesmos principios que, como antes foi elaborado, compõem a estrutura teórica básica da Lógica, constituem também a estrutura real da natureza e formam, assim, o núcleo teórico das Ciências Naturais. Deve haver aí uma correspondência exata. A argumentação que aqui se inicia trabalha, portanto, com um elemento a posteriori; a gente pega algo que está já préjacente - a natureza e as Ciências Naturais - e compara-o com as leis básicas da dialética que foram antes elaboradas. Aparece, então, ao fazermos esta comparação, uma correspondência? Lógica e natureza, consideradas ambas em seus princí- 
pios básicos, estão em correspondência? Esta forma de argumentar, que é pelo menos parcialmente a posteriori, não deve ser motivo de estranheza, pois, como mais acima na Lógica foi mostrado, a dialética nunca procede apenas de maneira a priori. Se isso vale na Lógica pura, no âmbito do falar e do pensar, por que não deveria valer quando se faz a passagem para a natureza? Não devemos aceitar sem crítica a pressuposição, errônea, de que o a priori possua uma dominância ou uma dignidade filosófica especial. O procedimento a priori - típico do racionalismo e da arquitetura da razão em Kant - não é um método universalíssimo que possa ser utilizado sempre e em qualquer circunstância, mas apenas um método complementar, que só possui validade em alguns casos e que só possui sentido pleno quando compreendido como sendo um elemento parcial de um todo maior que é o método realmente universal, isto é, como parte que entra na constituição do todo maior que é a dialética. Que isto seja assim, vê-se através da contradição que emerge quando se tenta universalizar o método a priori, tomando-o como sendo um método abrangente e universalmente válido para o pensar. Bons idealistas, como os bons realistas, sempre recorrem, no curso da argumentação, a elementos empiricos; eles sabem que precisam fazer isso para manter a distinção entre pólos contrários e contraditórios, distinção sem a qual simplesmente não se faz dialética (cf. acima 1.3.2.2., 1.3.3. e 2.). É por esta razão que a Lógica dialética, como foi esboçada acima, e as Ciências Naturais, como elas de fato hoje estão sendo feitas, são em princípio convergentes. Mas ainda há que se mostrar que esta convergência de fato existe, e até que ponto vai.

2.2 - Princípios: A correspondência existente entre os principios básicos da Lógica e os princípios básicos da natureza deveria ser desenvolvida tanto na Física como na Biologia. Lamentavelmente meus conhecimentos de Física são tão insuficientes que tenho que passar esta tarefa a outros que dela sejam capazes. Com referência à Biologia, a correlação, reduzida a palavras-chave, è a que segue.

\section{Princípios da Lógica}

\section{Princípios da natureza}

1. Identidade:

1.1. Identidade simples $A \ldots \ldots \ldots$ Indivíduo

1.2. Identidade iterativa $A A A \ldots \ldots$ Iteração, replicação e reprodução

1.3. Identidade reflexa $A=A \ldots \ldots$ Espécie

2. Diferença:

2.1. Diferença de contraditórios A e Não-A . . . . . . . . . . . (não existente)

2.2. Diferença de contrários

$A \in B \ldots \ldots \ldots \ldots$ Emergência do novo, mutação pelo acaso

3. Coerência:

3.1. Anulação de um dos pólos ........ Morte, seleção natural

3.2. Elaboração das devidas distinções . Adaptação

3.3. (História da Dialética) ......... História da evolução 
2.3 - A correspondência visivel nesta tabela comparativa pode ser, passo por passo, se não desenvolvida plenamente, pelo menos esboçada.

2.4 - Identidade simples (na Lógica) e indivíduo (na natureza): No começo está a identidade simples que se destaca do pano de fundo, ou seja, de seu meio ambiente, como sendo algo determinado. A partir deste primeiro começo desenvolve-se, então, formando processos longos e complexos, tudo aquilo que chamamos de universo. - A história da evolução das coisas foi, desde sempre, o primeiro e mais importante tema do mito e, quando este se depura como razão, da Filosofia. A história da gênese do mundo, bem como das coisas nele existentes, pertence aos fundamentos de nossa história, isto é, de nossa cultura. Desde os présocráticos os filósofos procuram formular, com o "ser", com o "nous", com os "átomos", com as "idéias", com a "substância", etc., os princípios que determinam a gênese e o desenvolvimento de nosso mundo complexo a partir de um primeiro começo que é simples. Ultimamente nós, filósofos - é lamentável - abandonamos quase completamente este tema, que talvez seja o mais importante de todos, e nos dedicamos quase só à análise das conexões existentes entre palavras. $\mathrm{O}$ ciclo das grandes questōes sobre a gênese do universo e da vida nós o entregamos aos físicos e biólogos que hoje tecem teorias bem razoáveis sobre a origem e o desenvolvimento do universo. Cosmologia antigamente era uma tarefa de filósofos e uma disciplina da Filosofia, hoje é assunto que só é tratado teoricamente por físicos e biólogos. Isso não deveria ser assim. Se a Filosofia quer ser fiel a seu nome e a sua tradição, então há que se colocar de novo, tentando respondê-la, a pergunta pelo sentido de nossa vida, a questão sobre o começo e o desenvolvimento do universo. - No começo está a identidade simples; o que é idêntico se destaca de seu meio ambiente. Chamemos este algo simples de "o determinado", ou, para usar uma terminologia mais atual, "sistema"; o meio ambiente, chamamos como tal. Um sistema, algo determinado, está no começo e se destaca e se distingue de seu meio ambiente, isto é, do caos. Não dá para dizer mais sobre isso, no começo não há muito para dizer. É claro que, aí, os princípios do ser que determinam o desdobramento ulterior da evolução já existem. Mas eles foram, antes, elaborados de forma apenas lógica; trata-se agora de mostrá-los no desenvolvimento da natureza.

\section{5 - Identidade iterativa (na Lógica) e iteração, replicação e reprodu-} ção (na natureza): A identidade simples, quando se repete, torna-se identidade iterativa. Ao primeiro " $\mathrm{A}$ " se acrescenta um segundo, um terceiro, um quarto " $\mathrm{A}$ ": "A", "A", "A", "A", etc. O segundo " $A$ " origina-se do primeiro? O segundo " $A$ " emerge a partir do primeiro? Isso afirmavam os neoplatônicos; é isso que entrou na doutrina sobre a trindade de Agostinho e, assim, na grande tradição da Filosofia. Mas não é esta a questão que agora nos ocupa; aqui nos interessa primeiramente o elemento da iteração, da repetição: é sempre o mesmo que vem e sempre de novo aparece; pelo menos, até agora. O universo consiste não mais de um simples "A", mas de "A", "A", "A", etc. que se repetem e se seguem uns aos outros. - Uma forma específica de iteração é a que se encontra no movimento elíptico, respectivamente circular, dos planetas e também dos elétrons que, girando em torno de um ponto central, descrevem sempre de novo a mesma órbita. Assim surgiram, no co- 
meço, os átomos e os sistemas solares. Uma outra forma de iteração, que encontramos, por exemplo, em cristais e seres vivos, é aquilo a que chamamos de simetria. Uma metade é, aí, a iteração, por espelhamento, da outra metade. Na Biologia a identidade iterativa aparece também como replicação e reprodução. Estes são hoje conceitos-chave que descrevem um aspecto fundamental de todo ser vivo e que, assim, entram na própria definição do que seja vida. Reprodução é o processo no qual um determinado organismo faz e deixa sair de si - "reproduz" - um outro ser vivo organizado de acordo com o mesmo plano de construção. Replicação é o processo no qual o plano de construção de um determinado organismo, codificado e empacotado no ácido nucléico, faz cópias de si mesmo. Reprodução é a iteração de organismos que são iguais uns aos outros. Replicação é a iteração de planos de construção que são iguais a si mesmos. Há aí, em toda a parte, presente e atuante, o princípio de identidade iterativa.

2.6 - Identidade reflexa (na Lógica) e espécie (na natureza): A identidade reflexa diz que o segundo (bem como o terceiro, o quarto, etc.) " $\mathrm{A}$ " é igual ao primeiro " $\mathrm{A}$ ", " $\mathrm{A}=\mathrm{A}$ ". Aparece aqui um fenômeno que desde a antigüidade nos faz cismar. Para poder dizer a identidade de "A", é preciso dizê-lo ou escrevê-lo duas vezes (primeiro à esquerda, depois à direita do sinal de igualdade); somente assim - através da posição explícita desta primeira diferença - é que podemos dizer plenamente a identidade de " $\mathrm{A}$ ". A diferença, a alteridade, ou simplesmente o outro, é o que aqui desponta e começa a emergir. Ainda estamos tratando do mesmo, daquilo que é idêntico a si mesmo, mas a diferença emergente começa a se fazer notar; percebe-se que há aqui um processo em curso no qual o idêntico sai de si para, depois, voltar a si mesmo. Este movimento circular é elemento característico da estrutura básica de muitas coisas importantes que aparecem mais tarde na evolução, como vida, isto é, ser autopoiético, ou pensamento e ação livre, isto é, espírito. Mas ainda não chegamos lá. A diferença ainda está apenas esboçada. - A esta identidade reflexa no âmbito da Lógica corresponde, no mundo dos seres vivos, a espécie. A espécie é aquela identidade na qual dois ou mais seres vivos individuais se igualam, sem com isso perder sua singularidade. $\mathrm{Na}$ espécie se expressa, não a singularidade ( $\mathrm{o}$ "isto" para o qual aponto com o dedo), mas a particularidade específica, a species, ou seja, aquilo que é comum aos muitos indivíduos. O plano de construção de uma determinada espécie, gravado nos genes de todos os indivíduos que a compöem, forma no decorrer da ontogênese a estrutura típica da espécie. Assim, de um ovo de galinha sai sempre e somente galinha. - Duas perguntas se põem aqui ao natural. Como se distingue o que é característica da espécie e o que é determinação do indivíduo? E segundo, por que a estrutura da espécie está gravada nos genes e as determinações individuais não? Ambas as questões levantam um problema que, no fundo, é o mesmo: a lenta e gradual emergência da diferença. Está gravado nos genes aquilo que lá está gravado (proposição tautológica). Esta gravação determina aquilo que é comum aos diversos indivíduos; a isto chamamos, então, de características típicas da espécie. As variaçōes individuais que sempre de novo aparecem no curso da ontogênese se originam do fato de que as instruções gravadas nos genes não são leis duras, não são regras que determinam tudo até o último pormenor; isto é, estas leis não impedem que surjam pequenas 
variações e, em certos casos, até contra-fatos. Estas leis, assim como o operador modal do Principio de Não-Contradição, são apenas um dever-ser. É claro que o dever-ser aqui não pode ser tomado no sentido estritamente humano de ética e de lei moral, mas apenas como uma lei da natureza que determina, sim, mas não determina tão fortemente como as leis da Lógica formal e da Matemática, a saber, até o último pormenor. O Princípio da Identidade diz, pois, igualdade, mas apenas uma igualdade tal e tanta que permita que também a diferença entre indivíduos exista. No caso de uma igualdade de cem por cento - nem mesmo gêmeos são assim - ainda há uma diferença espaço-temporal entre os indivíduos. Na maioria dos casos os indivíduos são determinados de modo que possuem relativamente muitas qualidades individuais. Se uma tal qualidade primeiramente individual (isto é, uma propriedade adquirida pelo indivíduo) entra no plano genético de construção, isto é, no mecanismo de replicação genética, então esta qualidade passa a fazer parte das caracteristicas da espécie e torna-se, assim, hereditária por reprodução. Se, ao contrário, a qualidade surgida de maneira individual (isto é, uma propriedade adquirida) não entra no plano genético de construção, então ela continua sendo uma propriedade apenas individual, ela é uma qualidade deste indivíduo, não da espécie. Se uma propriedade primeiramente individual entra ou não no plano genético de construção, isto é, se uma propriedade individual torna-se ou não uma propriedade da espécie, vê-se através da história da evolução. Isso - este é o grande tema de Lamarck - é inicialmente apenas um fato no curso de uma evoluçäo que decorre de maneira contingente. Quando e como uma propriedade individual entra no plano genético de construção, que circunstâncias físico-químicas são aí determinantes, sobre isso não temos ainda respostas satisfatórias. É exatamente este um dos temas que os biólogos hoje mais pesquisam.

\section{7 - Diferença de contrários (na Lógica) e emergência do novo, muta-} ção pelo acaso (na natureza): $\mathrm{O}$ outro, ou o que é diferente, aparece quando surge um "B" que é diferente do " $A$ " que se repete na série " $A$ ", " $A$ ", " $A$ ", etc. A alteridade do outro não se fez anunciar, ela não era previsível, ela não era calculável, ela não tem uma razão suficiente que a anteceda. De repente surge aí algo diferente. "B", sem que isso esteja dado ou pré-formado na série anterior "A", "A", "A", etc., ou na identidade reflexa " $\mathrm{A}=\mathrm{A}$ ". Este " $\mathrm{B}$ ", que é obviamente diferente de " $\mathrm{A}$ ", está para com " $\mathrm{A}$ " em oposição, não de contraditórios, mas sim de contrários. $\mathrm{E}$ assim como surgiu "B", surgem também "C", "D", etc. - Temos aí, primeiramente, a emergência do novo, sem que se pressuponha uma razão a ele pré-jacente, sem que se pressuponha uma causa eficiente que deva existir antes dele, sem que se postule antes de toda e qualquer galinha um proto-ovo de galinha. O diferente, bem no começo, surge como um caso, surge por acaso, ele é um acaso. No âmbito da Lógica tratava-se do pólo contrário, que não pode ser deduzido de maneira a priori (o pólo contraditório pode ser construido a priori, o contrário, não), na natureza trata-se do que é contingente, do que é por acaso. - O acaso é, tanto na Lógica, como também na natureza, um elemento muito importante, sim, um elemento necessário desta totalidade. Sem o acaso, isto é, sem a contingência, não haveria na Lógica a oposição de contrários e, por isso, não haveria dialética; sem o acaso a natureza seria apenas a explicação necessária (explicatio) daquilo que foi implica- 
do (implicatio) na semente inicial; a natureza não seria a história contingente de algo que poderia, por igual, ser e decorrer de modo diferente, mas o desenvolvimento necessário, o único possível, de uma substância à maneira de Espinosa. Fica claro que uma tal teoria necessitarista, isto é, que contém tão somente o elemento da regularidade, não corresponde às Ciências Naturais, tais como elas hoje descrevem e explicam a gênese e o desenvolvimento do mundo; fica claro também que uma tal teoria necessitarista impossibilita, por princípio, a contingência e, assim, a livre escolha entre diversas alternativas que sejam por iguais possiveis; com isso ficam impossiveis tanto a liberdade do homem, como também a verdadeira historicidade, como hoje a concebemos. Não caímos, porém, no caos total ao pôr o acaso, ou seja, a contingência na estrutura básica da teoria? Não, pois permanece mais aquilo que mais permanece. Com isso formula-se uma das mais importantes leis da natureza: a primeira lei da conservação.

\section{8 - Coerência, anulação de um dos pólos da oposição (na Lógica) e} morte, seleção natural (na natureza): A conservação do diferente é possibilitada e explicada, primeiramente, por um princípio simples: Permanece mais aquilo que mais permanece. Esta proposição é uma tautologia como " $A=A$ ". Proposiçōes tautológicas são sempre verdadeiras e valem não só no âmbito da Lógica, como também na natureza. Tais proposições, entretanto, nem sempre são vazias, como hoje muitas vezes se supõe, de conteúdo e de força explicativa. Em alguns casos, como aqui, o contrário é verdadeiro. A lei de conservação "Permanece mais o que mais permanece" explica muitíssimas coisas. Explica que só o duradouro, não o passageiro, permanece; explica que, em última instância, a ordem tem mais sucesso que a desordem. Se "B" e "C", etc. não permanecem mais, então não permanecem e desaparecem, voltando ao caos; e fica tão somente a série que se repete " $\mathrm{A}$ ", "A", "A", etc. Somente entidades estáveis perduram e continuam a existir. Esta primeira lei de conservação, formulada de maneira tautológica, diz também que há um princípio de seleção, que atua desde o começo na gênese e no desenvolvimento do universo. Só permanece mais o que mais permanece; isto é, só fica parte constitutiva do mundo o que é mais e o que dura mais que aquelas entidades que surgem e cintilam como faiscas por demais fugazes, para logo depois dissolver-se em nada. Permanece só o que se mantém a si próprio, ou então aquilo que através da repetição de si mesmo se dá consistência, isto é, o que através do movimento iterativo se torna uma mesmice durável. Todo o resto, tudo que é evanescente, tudo que não se repete, tudo que não se reproduz desaparece no curso do desenvolvimento, voltando à indeterminação e ao caos. Sem iteração, isto é, sem este movimento circular, que é próprio de elétrons e de estrelas, sem a replicação como ela ocorre no DNA, sem a reprodução como ela caracteriza os organismos, nada permanece por muito tempo. Dito de outra maneira, é a identidade iterativa que, sob a forma de movimentos orbitais, de replicação e de reprodução, dá consistência a todas as coisas. $\mathrm{O}$ diferente que surge, mas que não permanece mais e não se dá duração - através de movimentos circulares, replicação e reprodução - um tal ser diferente deixa de ser e desaparece. Ele existiu e durou por um breve espaço de tempo, mas não vingou. A lei de conservação, que está contida implicitamente no Princípio de Identidade Iterativa, já é, se aplicada às diferenças que surgem, 
uma lei de seleção. A assim chamada seleção natural, como disso se depreende, é uma forma mais específica de um princípio lógico simples.

A anulação de um dos pólos da oposição corresponde, na natureza, a morte. Na Lógica, a verdade de um pólo contrário implica a falsidade do outro; o pólo falso da oposição, exatamente por ser falso, não presta para nada e deve ser jogado fora do discurso racional. Na natureza chamamos isso de morte. - Na natureza, quando surge uma oposição de contrários, isto é, quando há um choque entre " $\mathrm{A}$ " e "B" - entre "sistema" e "meio ambiente" - duas coisas podem ocorrer. Primeiro, pode ocorrer que um pólo anule o outro. Em tal caso, só perdura um dos pólos, o outro, não. $\mathrm{O}$ pólo que perdura é então chamado - as mais das vezes só ao depois, ex post - de "vencedor"; o outro pólo não permanece, ele não sobrevive, ele morre. A isto corresponde, na Lógica, a anulação de um dos pólos da oposição, do pólo que é falso, pelo outro pólo, que é o pólo verdadeiro. Esta anulação se efetiva, na Lógica, de forma positiva: Se sabemos de uma fonte positiva qualquer - uma razão positiva, que não a simples estrutura da dialética como esquema - que um pólo da oposição é verdadeiro, então segue-se logicamente que o outro pólo é falso. Na natureza, como na Lógica, muitas vezes não se sabe antecipadamente, isto é, a priori, qual dos pólos da oposição é verdadeiro. A verdade e a falsidade de tese e antítese, na Lógica, devem ser demonstradas a partir de um argumento positivo (por exemplo, através de uma contradição performativa); também na natureza um dos dois pólos deve mostrar-se como sendo o "verdadeiro" ou o "correto". Esta "demonstração", na natureza, as mais das vezes näo é um nexo lógico, mas um fato. Um dos dois pólos da oposição, na natureza, vence; ex post constatamos isto e dizemos, então, que este pólo é o "vencedor", isto é, aquele que sobreviveu. O outro pólo desta oposição, o que no embate perdeu, este morre e desaparece de volta no caos. Isso não é uma filosofia da mera sobrevivência, uma filosofia aética, sem piedade e sem amor? Não. Se este raciocínio é levado conseqüentemente até o fim, chega-se, como se verá mais adiante (cf. 3.2. e 3.4.), a uma visão humanista do mundo, na qual aparecerão com clareza não apenas o homem em sua dignidade, mas também seu enraizamento na ordem cósmica.

\section{9 - As distinções devidas (na Lógica) e a adaptação (na natureza):} Voltemos à alternativa dura. Se na natureza há um choque entre dois pólos contrários, duas coisas podem ocorrer. Primeiro, pode ocorrer que um pólo, por ser "verdadeiro", anule o outro; é isto que vimos antes. Segundo, pode também ocorrer que, como acontece também na Lógica, ambos os pólos sejam "falsos". Dois pólos contrários não podem ser simultaneamente verdadeiros, mas podem ser simultaneamente falsos. O que acontece, na natureza, quando - isso ocorre seguido - ambos os pólos são falsos? Então aplica-se a mesma regra que já na Lógica resolvia o problema: Se ambos os pólos da oposição são falsos, então, para não ficar num beco sem saída, é preciso fazer as devidas distinções. Na Lógica tratava-se de aspectos lógicos que, uma vez elaborados e pronunciados, superavam e resolviam a contradição existente. $\mathrm{Na}$ natureza não se trata do pensar e do falar, e sim do ser. Os novos aspectos, que são necessários para superar a contradição existente realmente na natureza, são aspectos reais; são novos cantos, novas dobras, novas facetas que, em sendo reais, superam realmente a contradição que surgiu na natureza 
e que nela existe como algo real. A alternativa agora é a seguinte. Se há, na natureza, pólos contrários que são ambos falsos, isto é, que não são adequados, então duas coisas podem ocorrer. Ou um pólo anula o outro, ou - sendo ambos não adequados - a natureza gera novos aspectos reais (cantos, dobras, facetas etc.). Estes aspectos reais assim desenvolvidos superam, então, a contradição antes existente. A geração de novos aspectos, que na Lógica se chamava de "elaboração das devidas distinções", aqui na natureza atende pelo nome de "adaptação". Adaptação é a formação de aspectos reais que resolvem a contradição real antes existente e conciliam ambos os pólos num nivel mais alto, mais complexo e mais rico. "Sistema" e "meio ambiente", que antes estavam em oposição contrária, e que são ambos falsos, são conciliados e unidos através do engendramento de novos aspectos reais. Este engendramento de novos aspectos reais pode ocorrer no "sistema", como também no "meio ambiente", como também em ambos. A história da evolução dos seres vivos, que dá conta concretamente de como todas estas adaptaçōes ocorreram desde o começo até constituir o estágio atual, é chamada na Biologia de "evolução". É um mérito de Darwin ter reformulado esta velha teoria sobre o desenvolvimento do universo, concebida já pelos filósofos gregos e desenvolvida ulteriormente pelos mestres-pensadores da Idade Média e da Modernidade, e ter reunido, em comprovação dela, material empírico tão abundante e abrangente que podemos, hoje, discutir o assunto de forma científica. Decisivo neste contexto é, em minha opinião, a importância cada vez maior que se dá hoje ao acaso, isto é, à contingência; isso se percebe especialmente quando se compara as diferentes formas por que passou a teoria da evolução de Darwin até a teoria de sistemas de nossos dias.

\subsection{0 - História da dialética (na Lógica) e história da evolução (na na-} tureza): A evolução das coisas na natureza, assim como os movimentos lógicos da dialética, segue sempre - este é um lado - as regras necessárias, que foram discutidas na primeira parte, mas também sempre contém, como lá foi mostrado, - e este é o outro lado - a imprescindível contingência, isto é, o acaso. É por isso que a história da evolução, assim como a história da dialética, tem que ser escrita a posteriori. Há aí, por certo, um elemento que é necessário e a priori (o Princípio da Identidade, etc., inclusive o Princípio da Coerência), mas há aí também um elemento que é contingente e a posteriori. História se escreve quando se conta e se descreve, primeiro, - sempre, pois, ex post - como algo contingente se engendrou de maneira contingente e, depois, como este ser contingente se insere na rede de principios que são necessários e a priori. História é, portanto, como aliás tudo o mais na Lógica dialética e especialmente na natureza, uma união ou uma conciliação do que é necessário e do que é casual. - A história da evolução da natureza hoje é um dos temas centrais da Física e da Biologia. A história da dialética, que também sempre contém um elemento contingente, merece mais e mais a atenção dos pesquisadores. A filosofia alemã contemporânea trabalha intensamente nisso. 


\section{3 - ESPÍRITO}

3.1 - O que é espírito? Espírito é o estar-junto-de-si-mesmo (Bei-SichSein) do lógico que saiu de si e se alienou de si mesmo, tornando-se assim natureza, para, depois, voltar a si mesmo. Este voltar-a-si-mesmo chamamos, primeiro, de consciência - estar-junto-de-si-mesmo -, e numa forma ulterior de desenvolvimento, de espírito. Esta é a velha doutrina idealista desde Platão e dos neoplatônicos até o Cusano e Hegel. Não acrescentei nada a isto, exceto a ênfase na contingência e no acaso, bem como a elaboração da correspondência que existe entre a estrutura básica da dialética e as leis fundamentais da teoria da evolução de hoje. Um projeto de Filosofia do espírito deveria, aqui, traçar o esboço de uma Ética, de uma Antropologia, de uma Teoria do Conhecimento, de uma Filosofia do Direito e de uma Filosofia da História. Como as condiçōes de espaço e tempo não mais permitem, sejam bastantes as seguintes anotações, por demais sucintas, que tentam articular algumas idéias que julgo importantes para que a estrutura holística do presente projeto de sistema fique visível.

3.2 - A fundamentação da Ética: A primeira e mais importante questão de Ética consiste hoje em fazer, de maneira crítica, a passagem de proposiçōes descritivas para proposições normativas. Desde Hume, pelo menos, este é o grande problema da fundamentação da Ética. No projeto de sistema, que ora se apresenta, essa questão é resolvida, em minha opinião, de forma exata, embora simples, pois o dever-ser já aparece e é justificado bem no começo de todo o sistema, no começo da Lógica. Já nas duas primeiras partes do sistema, isto é, na Lógica e na natureza, o dever-ser é um conceito-chave. Todas as coisas, tanto na Lógica como na natureza, são determinadas por um dever-ser que aparece, primeiro, como o Princípio da Coerência, isto é, o Princípio da Contradição a ser evitada, e então como Princípio da Seleção Natural. É impossível argumentar, sem, desde sempre, pressupor o Princípio da Contradição a ser evitada; este dever-ser foi exposto no começo deste trabalho (1.3. e 1.3.1.). Quem pretende negar isto, ou sai do discurso ou está a repor exatamente aquilo que pretende negar. É um dever-ser, um operador modal deôntico - e não a necessidade lógica, o operador modal tradicional - que está no começo de toda a Lógica. Na natureza este dever-ser está alienado, ele está fora de si mesmo, mas exerce uma função decisiva como seleção natural (2.8. e 2.9.). Agora, na Ética, trata-se apenas de explicitar a faceta especificamente humana deste dever-ser. Pois no espírito, como na Lógica, mas em oposição à natureza, o deverser está plenamente consciente de si mesmo. Ética não é nada mais, mas também nada menos, que esse estar-junto-de-si-mesmo do dever-ser.

3.3 - O primeiro princípio da Ética: A segunda questão básica de toda Ética é, hoje, a seguinte: Qual é a característica, isto é, qual é o critério que distingue o bem do mal? Desde Kant a resposta que mais freqüentemente se dá a esta pergunta é o imperativo categórico, ou seja, a capacidade que uma regra tem de ser universalizada, como defendem, entre outros, Apel e Habermas. Bom é, portanto, aquilo que pode ser universalizado; a universalização se faz na roda concreta do discurso, na qual o discurso fáctico, embora ele mesmo seja contingente e real, an- 
tecipa a situação ideal do discurso. Quem nega esta situação ideal do discurso, sempre ínsita no discurso real (os princípios D e U de Habermas), está sempre, ao fazer isso, pressupondo aquilo que ele quer negar e envolvendo-se, assim, numa contradição performativa. Através disso - através da contradição performativa - dizem os defensores da Ética do Discurso, são demonstrados os dois princípios básicos de uma Ética geral. Concordo com quase tudo. Em minha opinião, tanto Kant, como também Apel, Habermas e todos os outros que se situam na tradição do imperativo categórico têm razão naquilo que afirmam de positivo. Errado, aí, é tão somente o fato de que param antes do tempo, de que não seguem mais adiante, de que consideram a universalização apenas como um agir subjetivo ou intersubjetivo. Errado, em minha opinião, é que o dever-ser e o ser-humano são concebidos, ai, de maneira muito estreita. Com relação ao dever-ser, tentei mostrar neste projeto que as três partes de um sistema da Filosofia - Lógica, Natureza e Espírito têm nele o primeiro princípio de determinação. Tanto o Princípio da Contradição a ser evitada (na Lógica), como o Princípio da Coerência ou da Seleção natural (na natureza), como também o imperativo categórico (na Ética) são apenas formas específicas de um mesmo e universalíssimo Princípio do Dever-ser. Para ampliar a Ética por demais subjetiva ou intersubjetiva da tradição de Kant e transformá-la numa Ética realmente universal, ou seja, ecológica, seria necessário mostrar que os conceitos de dever-ser e de homem precisam e podem ser correspondentemente ampliados. O homem, ou seja, o eu, não deve ser concebido de forma tão estreita, tão subjetiva, ou, falando duro, de forma tão mesquinha como usualmente se faz na Filosofia Contemporânea. Assim fazemos a passagem da Ética para uma Antropologia e uma Teoria do Conhecimento.

3.4 - Teoria do Conhecimento e Antropologia: Homem sou eu, nós somos homens. Eu sou um eu, todos nós somos um eu. Eu, entretanto, como sabemos da grande tradiçăo da Filosofia, năo é apenas este eu individual para o qual aponto com o dedo. Um tal eu não pode nem mesmo ser dito e expresso, sem que, no mesmo ato, seja dito um universal; o eu individual é desde sempre um eu universal. É isso que os mestres-pensadores ensinam; Hegel nos mostrou isto convincentemente no primeiro capítulo da Fenomenologia do Espírito e em muitos outros lugares. Hoje, entretanto, não tomamos muito a sério a lição de Hegel e dos mestrespensadores a este respeito. Aceitamos erroneamente, com o nominalismo, a tese de que o eu para o qual apontamos com o dedo seja o único eu verdadeiramente real, seja o único eu verdadeiramente existente. É claro que existem ainda um segundo eu, um terceiro eu, um quarto eu, etc., sempre um eu para o qual apontamos com o dedo, ninguém duvida disso. Mas um eu universal, isso não existe, isso é apenas um produto da fantasia, é uma metáfora que usamos para que o fenômeno da linguagem não fique tão incompreensivel assim. Aqueles de nós que não pensam de maneira tão nominalista - a maioria de nós hoje é nominalista - são kantianos mais ou menos envergonhados. Eles dizem, com Kant e contra o nominalismo, que existe um eu universal. Este eu universal, que eles, com Kant, chamam de transcendental, não é, porém, um eu que existe realmente, ele não é uma coisa que existe concretamente no mundo, mas tão somente uma rede de condições necessárias de possibilidade de que certos juizos sintéticos a priori, que todos 
os homens de fato têm como certos, sejam realmente verdadeiros (É interessante, e entrementes aceito por quase todos, que o método transcendental sempre comece a argumentação a partir de um fato, ou, em outras palavras, que sempre pressuponha um fato). Este eu universal, o eu transcendental, não é um ente, também não é o próprio ser dos entes, mas apenas um "valer". O mundo real e as coisas reais do mundo, como são em si mesmas, para o filósofo transcendental são e permanecem em princípio desconhecidas. Não se nega a existência delas, na prática pode-se até precisar delas; elas são acessiveis à razão prática, não à razão teórica. Este é o lugar em que o filósofo transcendental de hoje, as mais das vezes sem o conceder abertamente, torna-se empirista. - Nesse vaivem entre nominalismo, transcendentalismo e empirismo perdemo-nos mais e mais - sim, muitas vezes sem encontrar solução - no emaranhado dos múltiplos e coloridos fios tecidos pelos velhos gregos. De um lado estão as coisas; elas são individuais, são extensas, são espaçotemporais, são contingentes. Do outro lado está o conhecimento; as idéias ou conceitos, no conhecimento, não são individuais, mas sim universais, não são extensos, e sim inextensos, não são espaciais nem temporais, e estão numa rede de conexões necessárias, uns para com os outros. $\mathrm{O}$ mundo das coisas e o mundo das idéias estão desde Platão em contraposição, um contra o outro, e as tentativas de superar o abismo existente entre ambos ficaram até agora - isso precisamos conceder sinceramente - sem resultado satisfatório. Também a construção de um eu transcendental apresenta, como sabemos, certos traços de uma esquizofrenia filosófica e só a aceitamos porque não temos nada de melhor à disposição para pôr no lugar dela. Não temos solução que seja realmente melhor? Temos, penso eu, solução muito melhor. Desde Platão que a temos, só que sempre de novo esquecemos como os componentes desta solução, isto é, as partes integrantes desta teoria, se ajustam e se encaixam uns nos outros. É mérito de Humberto Maturana ter, hoje, redescoberto e reformulado de novo a velha pergunta e sua solução clássica. Não me atenho, porém, a Maturana e, em certos trechos indo além dele, construo o argumento à medida das necessidades desta exposição.

É preciso, para chegarmos a um resultado que seja razoável, analisar e entender idéias e conceitos no quadro mais amplo da questão sobre o conhecimento em geral. Por conhecimento entendo primeiramente uma forma especifica do agir em conjunto de homens, como aqui vou descrever e montar, passo por passo, em sua estrutura conceitual. - Um exemplo sirva de esclarecimento. Um homem individual, que vive num grupo com outros homens individuais, pode agir tanto de maneira individual como também em conjunto com outros homens. Assim acontece na caça, no rodeio de gado, na plantação e na colheita. Se um indivíduo desse grupo quiser levar para um rio próximo um tronco de madeira, pesado, que está no meio do mato, para com ele construir uma balsa, precisa para isso de auxilio de outros, isto é, da cooperação de três ou quatro homens do grupo, pois um sozinho não consegue levantar o peso. Suponhamos, agora, que todos estão de acordo e que, juntos, põem mãos à obra. Eles agarram, juntos, o tronco de árvore e o levantam do chäo, carregando-o, em conjunto, para o rio. A palavra importante, aqui para esta análise, é "juntos" ou "em conjunto". Pois, se nas circunstâncias descritas a ação não for conjunta, nada se consegue. Para o individuo sozinho o tronco de árvore é pesado demais. É preciso, por ísso, agir em conjunto. Essa ação em con- 
junto, para ser executada na prática, necessita de um sinal, por exemplo, um som flatus vocis - que permita que cada um coordene de maneira rítmica seu esforço individual com o dos outros: todos têm que pegar ao mesmo tempo. "Oi-ho" dizem nossos lenhadores. No "oi" a gente se prepara, no "ho" se emprega toda a força. Sem este "oi-ho", repetido sempre de novo de forma rítmica, a coisa não anda porque falta o ritmo que marca a simultaneidade do esforço conjunto, ou, antes, que marca o em conjunto. Carregar o tronco de árvore é um agir conjunto; isso é algo concreto, que pode ser fotografado e filmado; isso não é abstrato, e sim um agir conjunto que é concreto. A palavra primeva "oi-ho" é igualmente concreta e pode ser gravada em fita magnética; ela pertence a esta situaçäo concreta como uma parte pertence a uma totalidade maior. Pressuponhamos, agora, que um destes homens, mais tarde, em outra situação - o grupo está sentado após uma refeição e descansa - emita o som "oi-ho". O que acontece? Os outros vão olhar para ele, espantados, pois o som "oi-ho", conhecido de uma situação concreta determinada, está sendo agora emitido fora do contexto anterior que era o de uma determinada ação conjunta, na qual ele se originou e à qual ele pertencia; a parte aqui está sendo tirada da totalidade, à qual ela originariamente pertence. O som "oi-ho", que antes era um todo dentro de um todo maior (pars in toto), é tomado agora de maneira abstrata, ele é tirado do contexto ao qual pertence (abs-trahere). E, apesar disso, todos os que ouvem o som, emitido agora fora do contexto concreto de origem, relembram a ação conjunta de carregar, executada antes por esforço conjunto. O som, tirado de seu contexto original e assim "abstrato", remete à situação em que se originou e a partir da qual se entende: o ritmo da açäo de carregar, em conjunto, um peso que não é leve. Agora o som "oi-ho" não é mais uma pars in toto; o som é usado fora da situação concreta do agir em conjunto, mas ele continua remetendo para a situação que não perdura mais. O som agora é usado de forma abstrata; ele não é mais pars in toto, mas continua sendo uma pars em relação a um totum, ele é uma pars pro toto. $\mathrm{E}$ assim se originam os sinais, que não são aquilo que eles significam; eles significam sempre muito mais do que eles realmente são. - Abstração é, portanto, aquela transformação que a pars in toto sofre quando, tirada da situação original, fica uma pars pro toto, uma parte que remete para um todo que não está mais presente. - Este agir em conjunto eu chamo de universal concreto; o som que é abstraído do contexto concreto e que agora funciona como sinal eu chamo de universal abstrato. O universal abstrato só tem sentido, e só pode ser entendido, se e enquanto o ouvinte - e/ou o participante dos atos de fala - possui ou adquire a capacidade de remeter o sinal (isto é, o universal abstrato) à situação original (isto é, ao universal concreto). A pars pro toto só é compreensivel se e quando a tornamos presente como pars in toto. $\mathrm{O}$ universal abstrato é, tanto do ponto de vista lógico, como também do epistemológico e do ontológico, tão somente um elemento que entra na constituição do universal concreto e para ele remete. Se o universal abstrato é afastado para longe demais do universal concreto, ou se é desconectado totalmente deste, então nada mais se entende, então o sinal não significa mais nada. Pois conhecer o sentido de uma língua, isto é, conhecer o sentido de sinais é apenas a relembrança do universal concreto, no qual os sinais originariamente eram pars in toto e do qual foram então abstraidos para funcionar como uma língua (pars pro toto). 
Eu sou eu, nós somos um eu. Que é o eu? Eu não sou tão somente este indivíduo para o qual apontamos com o dedo. Claro, eu, tu, nós todos somos, entre outras coisas, também um eu para o qual apontamos com o dedo. Eu é, parece, primeiramente um eu individual. Mas o eu é, mais do que o simples indivíduo, um grupo. Eu é também um nós. Neste "nós" o eu individual está contido; mais, ele está ai suprassumido (aufgehoben) no sentido de Hegel. Pois no nós se fundem em uma unidade tanto o eu individual como também o outro eu também individual - 0 tu - de maneira que a individualidade singular do eu é dissolvida, sem que com isso o eu se perca. Esta conciliação dos eus individuais, inicialmente contrapostos, chamo agora de "eu particular". O eu particular aparece como universal concreto sempre que homens caçam, pescam, trabalham, etc., em conjunto. Uma forma mais específica ainda do eu particular aparece quando homens falam uns com os outros, isto é, quando desenvolvem uma língua. Pois é através da lingua, que é ela mesma uma forma específica do eu particular, que os homens conseguem superar os limites da particularidade, e é nela que o eu se torna também meio ambiente, para em última instância ampliar-se como universo. Isso, agora, chamo de eu universal. - A ampliação do eu individual, primeiro para um eu particular (isto é, nós), depois para um eu universal (isto é, mundo e universo), foi aqui descrita na seqüência acima, pois nós adultos somos muitas vezes levados por nossos preconceitos e precisamos bastante tempo para deles nos libertar. A rigor, para sermos exatos, não deveriamos falar de uma ampliação, como fizemos, mas sim, com Piaget, de uma particularização do eu. Pois o eu é primeiramente um universal do qual, então, o eu particular se particulariza (tomar a palavra ao pé da letra) para depois, e somente a partir de aqui, sentir-se e saber-se como sendo um eu individual. Voltamos assim à dialética do conceito de Hegel, conceito este que é desde sempre e simultaneamente (embora sob aspectos diferentes) um eu singular, um eu particular e um eu universal. Eu não sou apenas eu, mas eu também sou nós, e além disso eu também sou mundo, ou seja, sou todo o universo.

O imperativo categórico, que é o primeiro princípio da Ética, diz de maneira apenas subjetiva aquilo que acima expusemos de forma ontológica e epistemológica. As ações são boas se e enquanto não estão em contradição com o eu singular, com eu particular, com o eu universal. É por isso que o dever-ser ético dos homens não está limitado às ações que dizem respeito a outros homens, mas vige também com relação ao meio ambiente e, em última instância, a todo o universo. A teoria aqui exposta e defendida não é, pois, apenas uma doutrina da sobrevivência do indivíduo singular, mas uma teoria da coerência a ser vivida não somente com os outros homens, mas também com a natureza (isto é, ecologia). Importante aí é, não o eu enquanto mero indivíduo, mas o eu individual enquanto está afinado com o eu particular (família, sociedade, Estado) e com o eu universal (mundo, universo). 0 importante não é a mera sobrevivência do individuo, mas o concerto com o processo global do mundo. Não se trata, pois, de um darwinismo social sem dó nem piedade, mas de uma ética humanista como a conhecemos da tradição.

3.5 - Filosofia do direito: Eu sou nós. Primeiro sou familia, depois, sociedade, finalmente sou também Estado; a divisão de Hegel parece-me ser ainda a melhor. Na familia sou um nós, um eu particular, que está em parte na natureza, em 
parte no espírito. A sociedade é já uma forma mais desenvolvida do eu particular, na qual os homens constroem uma vida em comum com maior grau de liberdade $e$ na qual o espirito se encontra consigo mesmo como cultura. No Estado ou na federação dos Estados (esta falta em Hegel, mas já está presente em Kant) o eu particular chega a sua culminação, ao engendrar a lei e a justiça. O Estado é bom, se e enquanto sua constituição é boa; esta é boa, se e enquanto ela é aprovada pelo julgamento da História. Isso remete à Filosofia da História.

3.6 - Filosofia da História: História é primeiramente a história da evolução. Como começou? O que ocorreu? História neste primeiro sentido é apenas a enumeração das diversas etapas evolutivas, isto é, a enumeração de fatos. História possui ainda um segundo sentido, que é mais importante que o primeiro. História é a consciência, que o eu sempre já possui, de que o eu individual é sempre um eu universal e que ele precisa agir, pensar e avaliar como tal. História é, assim, sempre também uma Ética, isto é, uma avaliação ética de tudo aquilo que ocorreu, como, além disso, um projeto ético para o futuro. História, assim, não é apenas um desenrolar-se de eventos vazios de valores éticos, ela também não é o curso mecanicamente necessário de uma vida determinada pelo destino, ela também não é uma evolução duramente linear das coisas, uma evolução que, sem contingência e acaso, não oferece alternativas e, por isso, näo permite verdadeira liberdade de escolha, ela também não está previamente determinada por uma predeterminação da providência divina, nem por algum ardil da razão. História é, pelo contrário, o relato daquilo que durante a evolução se desenvolveu; é preciso, aí, manter sempre presente o universal concreto, isto é, o universo cósmico, e, por isso, atribuir a cada acontecimento a devida valoração ética. Este relato vai contar como as múltiplas peças se encaixam e se ordenam, como parte em um todo, formando um grande mosaico. Mas o tempo ainda corre e a história não chegou a seu fim. Os juízos de valores, que pertencem constitutivamente à História, precisam ser confirmados ou corrigidos por cada homem singular. É por isso que a História tem que ser repensada e reescrita por cada eu individual. $\mathrm{O}$ autor do roteiro da História não é, pois, uma razão abstrata, também não uma Lógica abstrata, mas aquele logos que discutimos na primeira parte deste projeto de sistema, que primeiro se alienou como natureza, e que, agora, como espírito, se desenvolve em nós e por nós mesmos. Somos, portanto, co-autores verdadeiros e legitimos, embora modestos, do grande roteiro da História Universal. Pois o eu singular, que eu sou, só é um eu enquanto ele é também um eu particular e um eu universal. $\mathrm{O}$ eu individual age de maneira ética quando ele, de acordo com o imperativo categórico, decide e age não apenas como um eu só individual, mas também como o eu particular e o eu universal que ele realmente também é. $\mathrm{O}$ eu é sempre, tanto do ponto de vista lógico, como também ontológico, e, por isso, também do ponto de vista da Ética e da Filosofia da História, a conciliação dialética entre o singular, o particular e o universal. Assim, o imperativo categórico de Kant, que é um princípio só do sujeito, transforma-se num princípio lógico e também ontológico de dever-ser que tudo abrange e tudo determina. Os ecologistas de hoje, e não Kant, têm razão neste ponto. Esta estrutura dinâmica do eu, que tem tanto um elemento individual como um elemento social e cósmico, é, como se sabe, uma característica da Filosofia de Hegel. Hegel é her- 
deiro da tradição dos filósofos neoplatônicos e de Meister Eckhard; no fundo, tratase aí do velho projeto de Filosofia do Hen kai Pan, que apresento aqui, numa forma bem mais moderada, como projeto de sistema aberto. Em oposição a Hegel e aos mestres-pensadores da antigüidade, eu ponho a contingência dentro da própria estrutura do projeto de sistema; isso aprendi de Nietzsche e de Heidegger. Com isso a Filosofia não se coloca jamais como uma ciência pronta e acabada; ela não abandona seu velho nome e continua sendo somente um projeto sempre inacabado e incompleto, sempre só "amor à sabedoria". 